\title{
Open Impacts Workgroup Report
}

\author{
John Dove, Jason Hoyt, Rebecca Kennison, Natalia Manola, Trevor Owens
}

\section{Abstract / OSI2016 Workgroup Question}

This report summarizes the discussion of the Open Impacts workgroup held at the Open Scholarship Initiative meeting in Fairfax, VA, April 19-22, 2016. The workgroup tackled the following questions at OSI2016: How fast is open access growing? Is this fast enough? Why or why not? What are the impacts of currently evolving open systems? For instance, are overall costs being reduced for scholarly libraries? Is global access to scholarly information increasing? What about in the Global South? What is the impact in this region of increasing adoption of the author-pays system?

Society would be better off if the future were one of 100 percent open scholarship, including immediate open access to publications and to data. That hope, which is shared by most, must be allowed to shape how we act today if we are going to achieve such ambition. We must feel empowered to create change, but such change will require setting targets and developing the strategies, studies, and reflection to get there. A house cannot be built without first understanding the soil that it will rest upon and how the environment will be impacted.

Foundational, then, is that we have accurate and ample data in order to support the lofty goals of open scholarship. We believe such data is necessary to understand the effects that any strategies and targets for open scholarship will have upon all stakeholders.

Each discipline and stakeholder will have its own idiosyncratic needs and reflexes, thus there must be a specific data-gathering approach by and for each field to understand the impact of moving toward open scholarship.

To create the open impacts measures that we believe are needed to achieve such change, we wish to target reward and evaluation systems, the transparency of academic publishing costs, support for new scholarly communication mediums, and improved text and data mining.

There are already numerous case studies on these issues. We lack milestones, goals, and widely accepted routine measures. In short, we need to know where we've been and where we are in order to go where we want to be.

We know the "why" of data capturing, but to arrive at the who, how, and what requires study and debate between and among all stakeholders. Therefore, we have aimed to set forth a launch pad with this document for others to build upon in determining the impact(s) of becoming open. We set out three high-level areas in a framework to create an agenda for going

(C) 2016 OSI2016 Open Impacts Workgroup. This open access artide is distributed under the Creative Commons Attribution 4.0 International License. This document reflects the combined input of the authors listed here (in alphabetical order by last name) as well as contributions from other OSI2016 delegates. The findings and recommendations expressed herein do not necessarily reflect the opinions of the individual authors listed here, nor their agencies, trustees, officers, or staff. 
forward: measuring openness, measuring the use of open, and understanding the economic impacts of open. Finally, we conclude with a target to fill the knowledge gaps.

As the initial workgroup for "Open Impacts," we have gone in circles, found our way out again, only to then paint ourselves back into a corner once or twice. A look back on where we've already been may be helpful to future groups looking to extend this work.

The initial question we asked ourselves was "what should we be working on or solving?" Preliminary discussions of the workgroup's remit fell into four loosely defined categories:

\begin{tabular}{|c|c|}
\hline $\begin{array}{l}\text { We should set spe- } \\
\text { cific targets }\end{array}$ & $\begin{array}{l}\text { - By [X year] scholars should be able to incorporate } 2 \mathrm{x} \text { as } \\
\text { much research in their work as they do now. } \\
\text { Businesses and jobs based on access to scholarly literature } \\
\text { should measurably increase year on year. } \\
\text { - Discipline by discipline we should arrive at a point where a } \\
\text { broad consensus exists by [X year] that scholars and institu- } \\
\text { tions anywhere in world can get by with only what's available } \\
\text { for free on the Internet. } \\
\text { - By [X year] at least } 60 \% \text { of academic libraries have "flipped" } \\
\text { from pay-wall to open access. } \\
\text { - The majority of scholarly output will be allowed to be ma- } \\
\text { chine-readable by } 2020 \text {. }\end{array}$ \\
\hline $\begin{array}{l}\text { We should define } \\
\text { the stakeholders } \& \\
\text { impacts }\end{array}$ & $\begin{array}{l}\text { Map out who the stakeholders are and explore the kinds of } \\
\text { impacts that should be better understood for each of those } \\
\text { groups. } \\
\text { Is there a set of measures and recommendations we can } \\
\text { come to that might apply to all stakeholders? }\end{array}$ \\
\hline $\begin{array}{l}\text { We should gather } \\
\text { existing data }\end{array}$ & $\begin{array}{l}\text { - What } \% \text { of literature is currently open access? } \\
\text { - What are the costs of open scholarship? } \\
\text { - Which fields are already open enough? } \\
\text { - What are the impacts of openness on libraries, the public, } \\
\text { current systems, etc.? } \\
\text { - Where and how can we get the data in a con- } \\
\text { sistent/systematic way to know where we are and how to } \\
\text { measure progress? }\end{array}$ \\
\hline $\begin{array}{l}\text { We should deter- } \\
\text { mine which data to } \\
\text { capture }\end{array}$ & $\begin{array}{l}\text { - Desire for good measures. } \\
\text { - Approaches to measurements. } \\
\text { - How do we measure progress in open scholarship? }\end{array}$ \\
\hline
\end{tabular}

Table 1. Proposed categories discussed for what should be the initial workgroup's remit and outputs.

Given our short timeframe, we determined in the end that specific targets (Table 1) related to open scholarship were out of scope for our workgroup. We also concluded that an attempt to gather existing data within the workgroup's limited 
hours would be of minimal value. Such an exercise could, however, be part of a future workgroup or more likely a task for organizations created or enlisted and devoted to such.

Similarly, even defining who all of the stakeholders are and the impacts upon them seemed to be both too granular and too expansive for an initial workgroup gathering. It seemed neither realistic nor productive to develop consensus on measures since we were working in the abstract. We will not be able to come up with a concrete plan for measurement without a budget, timeline and other real world constraints.
Therefore, we decided to focus on developing a general framework for understanding what data to gather on the impacts of open scholarship.

\section{Three areas for an Open Impacts framework}

The team ended up with three different high-level areas of foci to create the agenda for understanding open impact (Fig. 1):

1. Measuring openness

2. Utilization measures

3. Understanding economic impacts of open

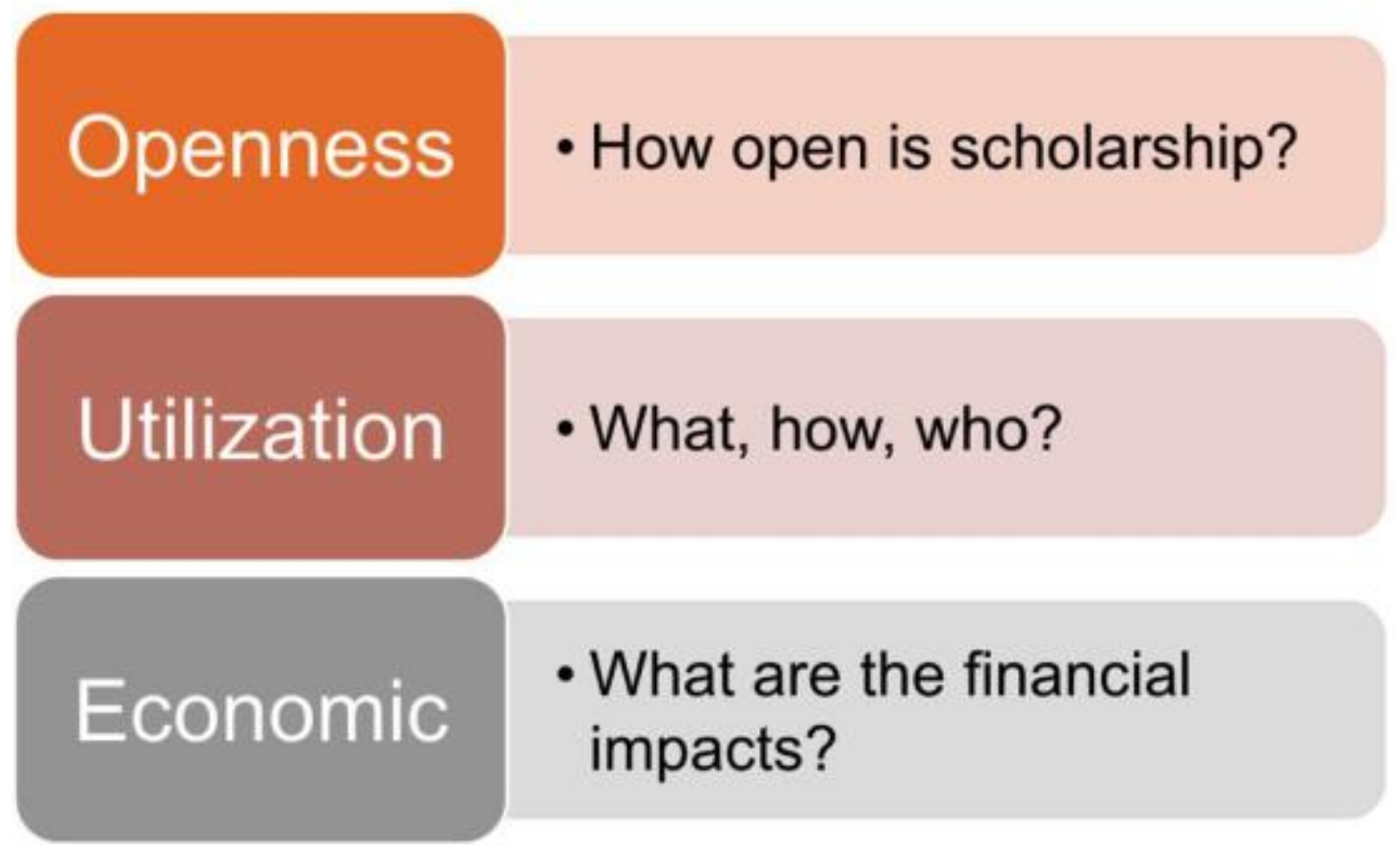

Figure 1: Three areas of the Open Impact framework

Measuring openness is a near-term opportunity to establish key baseline measures for how open scholarship is deployed in different fields and at different institutions. It would also be useful for policy makers (e.g. funders, institutions) to have insight into the effectiveness of an open access policy. Finally, such measures can help all stakeholders (publishers, funders, scientists, institutions, etc.) measure their progress towards openness in their field. 


\section{Measuring Openness}

To determine how open scholarship may be for particular fields we found it helpful to define the possible measures and group them by domain (Table 2). Challenges for future workgroups abound:

- There is a need to firm up common measures for what will be counted and how. This will require stakeholder consensus.

- Who will do this work? Existing projects need to be coordinated on a global scale, resources secured, data collected and curated, and so on.

- Which incentives can be recognized and developed to drive participation?

- How will any pilot projects scale?

\begin{tabular}{|c|c|c|c|c|}
\hline Products & $\begin{array}{l}\text { License } \\
\text { measures }\end{array}$ & $\begin{array}{l}\text { Availability } \\
\text { measures }\end{array}$ & $\begin{array}{l}\text { Permanence } \\
\text { measures }\end{array}$ & Format measures \\
\hline $\begin{array}{l}\text { - Artides } \\
\text { - Monographs } \\
\text { - Data } \\
\text { - Software } \\
\text { etc. }\end{array}$ & $\begin{array}{l}\text { - Creative } \\
\text { Commons } \\
\text { - Free to read } \\
\text { - Free to mine } \\
\text { - Embargoed } \\
\text { and embargo } \\
\text { length } \\
\text { - Pay-walled }\end{array}$ & $\begin{array}{l}\text { Different ways to meas- } \\
\text { ure availability [needs } \\
\text { more research]. Exam- } \\
\text { ples: } \\
\text { - Metadata quality, } \\
\text { - Discoverability, } \\
\text { - Crawling } \\
\text { - Machine readability } \\
\text { - Links to other re- } \\
\text { sources } \\
\text { - Public access to usage } \\
\text { data }\end{array}$ & $\begin{array}{l}\text { Official certification } \\
\text { - Yes } \\
\text { - No } \\
\text { - No but committed } \\
\text { to long-term } \\
\text { preservation }\end{array}$ & $\begin{array}{l}\text { Per file formats (e.g., } \\
\text { PDF, PDF-A, HTML, } \\
\text { embedded figures, } \\
\text { tables, csv, xls, json, } \\
\text { xml) }\end{array}$ \\
\hline
\end{tabular}

Table 2: Measuring Openness: metrics devise to address openness.

Recommendation: Work and organizations already exist, that can be leveraged to coordinate this work. Examples include, but are in no way limited to VIVO, SHARE Notify, OpenAIRE, SPARC, ORCiD, CrossRef, and USUS.

Our recommendation in this area is to create an "Openness Score" based upon Table 2. This score could apply to specific research objects, aggregated by object to disciplines, funders, institutions, etc. An Openness Score Summit could be organized. Such a summit would involve all stakeholders, including those collecting data. This meeting's initial focus would be to establish a plan for developing the infrastructure, funding, and sustainability needed. It would also focus on aligning with existing infrastructures. The key output should be a strategic, organizational, and technical plan for how the data above would be collected, organized, coordinated and managed. 


\section{Utilization measures}

This is the "who" and "what" for the various types of use. Leveraging the available information, a key consideration is

\begin{tabular}{|l|l|}
\hline Current use & Possible Metrics \\
\hline To grow global and national economies & $\begin{array}{l}\text { New job sector growth, invention-to-prod- } \\
\text { uct time }\end{array}$ \\
\hline To increase literature access & $\begin{array}{l}\text { Page reads, downloads, citations, derivative } \\
\text { works (translations, reuse of figures), num- } \\
\text { ber of publications, machine usage, time on } \\
\text { site, altmetrics, geo-location, etc. }\end{array}$ \\
\hline To gain access to more data & $\begin{array}{l}\text { Page reads (number, distribution, reader } \\
\text { ID), downloads, references in non-academic } \\
\text { sources, increased diversity in readers, } \\
\text { crowd sourcing/funding }\end{array}$ \\
\hline To support education (K-12, higher ed) & $\begin{array}{l}\text { Access frequency, distribution, user ID, } \\
\text { citations, crowd sourcing/funding. }\end{array}$ \\
\hline To accelerate innovation & $\begin{array}{l}\text { Access by learners, references in educational } \\
\text { material, programs, lesson plans, syllabi }\end{array}$ \\
\hline To facilitate archiving and curation & $\begin{array}{l}\text { Use in patent applications, number of pa- } \\
\text { tents arising, investment growth }\end{array}$ \\
\hline
\end{tabular}

Table 3: Utilization measures.

Recommendation: We were split in our recommendation. Some delegates suggested that several working groups should be created in order to tackle this effort in coordination. Such working groups could include the National Information Standards Organization (NISO) and the Research Data Alliance (RDA) to propose standards for open access usage metrics to be adopted by the community at large that would include published material provided via publishers, content in institutional repositories, domain specific repositories, and funder repositories like PubMed, and other sources of research output. Following this path we would strongly encourage that any U.S. initiative be aligned with existing initiatives: Impact Story for alt- whether a common approach can be established. We defined categories of current uses of open scholarship and a limited set of possible metrics for each (Table 3). 
democratization of innovation, increase in cross domain research, change of peerreview, disruption to the academic publishing industry, job placement at universities, institutional ranking, etc.

Recommendation: We agreed that economic impact is too broad to address through specific measures and needs to be analyzed via ongoing inquiries. We recommend that one or more funders explore this domain in the areas listed above and more. We recommend that as part of this effort the Open Scholarship Initiative
(OSI) establish a research agenda for open scholarship if an existing program does not yet exist somewhere else in the scholarly community. Subsequent OSI meetings could include a program aiming to address the economic impact. Finally, we suggest gathering a diverse stakeholder group to define reasonable metrics for the publishing industry, as well as identify the socioeconomic impacts of open access policies.

\section{OSI2016 Open Impacts Workgroup}

Jean-Gabriel Bankier, President, bepress

John Dove, library and publishing consultant

Jason Hoyt, CEO, PeerJ

Rebecca Kennison, Principal, K|N Consultants

Natalia Manola, Director, OpenAIRE

Trevor Owens, Senior Program Officer, Institute of Museum and Library Services (IMLS)

Christopher Thomas, Administrator, Defense Technical Information Center (DTIC), US Department of Defense

Jack Schultz, Director, Christopher S. Bond Life Science Center, University of Missouri

Neil Thakur, Special Assistant to the Deputy Director for Extramural Research, NIH, and program manager for the NIH Public Access Policy 